\title{
Starch, growth, and development in cuttings of rootstock 'Paulsen 1103' from plants infested with ground pearl
}

\author{
Amido, crescimento e desenvolvimento de mudas de videira \\ 'Paulsen 1103' oriundas de plantas matrizes infestadas por pérola-da-terra \\ Marcelo Zart $^{\mathrm{I}}$ Henrique Pessoa dos Santos ${ }^{\mathrm{II}}$ \\ Paulo Vitor Dutra de Souza ${ }^{\text {III }}$ Daniel Antunes Souza ${ }^{\text {II }}$ Diana Denardi ${ }^{\text {II }}$
}

\section{ABSTRACT}

The ground pearl, Eurhizococcus brasiliensis, is considered an important pest of vineyards in southern Brazil, with affected plants exhibiting leaf chlorosis, reduction in vigor, fading, and death. This study evaluated the quality of hardwood cuttings produced from plants infected (I) and not infected (NI) by ground pearl. 'Paulsen 1103' (Vitis berlandieri $\times$ Vitis rupestris) plants were grown for 29 months in brick-built raised beds either infested or not infested by ground pearl; then, 12 one-year-old branches with a maximum of 12 buds each were cut from each plant, subdivided into three portions (4 buds cutting ${ }^{-1}$ ), and subjected to destructive and nondestructive testing. DDestructive testing comprised determining fresh and dry weight, length, internode diameters, and percentage of starch. Nondestructive testing comprised assessing the potential for bud sprouting and shoot development. Each mother plant in the I and NI beds was considered a replicate, with a total of 360 cuttings per treatment. It was observed that cuttings from infected plants had significantly lower $(P<0.05)$ internode diameter, length, and fresh and dry weight than those of the uninfected plants. The percentage of starch content of the cuttings did not differ significantly. All cuttings showed the same percentage (100\%) of bud breaking and no changes in growth and development of seedlings regardless of source. Given these results, it was concluded that vines of 'Paulsen 1103 'infested with ground pearl produce smaller cuttings than those of uninfected plants but with no reduction in bud break percentage or seedling development.

Key words: Margarodidae, Vitaceae, insect-plant interaction, carbohydrates.

RESUMO

A pérola-da-terra, Eurhizococcus brasiliensis, tem sido considerada uma importante praga dos vinhedos no sul do Brasil, sendo que as plantas atacadas manifestam clorose foliar, redução no vigor, definhamento e morte. Este trabalho teve por objetivo avaliar a qualidade de estacas lenhosas produzidas a partir do contraste de videiras infestadas (I) e não infestadas (NI) por pérola-da-terra. Após 29 meses de cultivo em canteiros de alvenaria, em presença ou ausência de pérola-da-terra, cada planta da variedade 'Paulsen 1103' (Vitis berlandieri $\times$ Vitis rupestris) foi submetida à retirada de 12 ramos de ano, com no máximo 12 gemas cada, sendo subdivididos em três porções (4 gemas estaca ${ }^{-1}$ e submetidos a avaliações destrutivas e não destrutivas. As destrutivas consistiram em determinar massas fresca e seca, comprimento, diâmetro de entrenós e percentual de amido. As avaliações não destrutivas consistiram em testar o potencial de brotação e desenvolvimento das estacas. Cada planta matriz dos canteiros I e NI foi considerada uma repetição, totalizando 360 estacas por tratamento. As estacas das plantas infestadas tiveram uma redução $(P<0,05)$, em relação às não infestadas, em diâmetro, comprimento e massas fresca e seca. Não houve contraste significativo do percentual de amido avaliado das estacas. Quanto à brotação, destaca-se que todas as estacas apresentaram o mesmo percentual (100\%), independente da origem, sem alterações no desenvolvimento e crescimento das mudas. Diante desses resultados, salienta-se que videiras 'Paulsen 1103' infestadas por pérola-da-terra produzem estacas menores, porém não há comprometimento no percentual de brotação e desenvolvimento das mudas, quando comparadas com plantas não infestadas.

Palavras-chave: Margarodidae, Vitaceae, interação insetoplanta, carboidrato.

\section{INTRODUCTION}

Brazilian viticulture has had remarkable growth in crop and grape production in recent

\footnotetext{
'Universidade Estadual do Norte do Paraná (UENP), Cornélio Procópio, PR, Brasil.

IIEmbrapa Uva e Vinho, Rua Livramento, 515, CP 130, 95701-008, Bento Gonçalves, RS, Brasil. E-mail: henrique.p.santos@embrapa.br. ${ }^{*}$ Corresponding author.

IIIDepartamento de Horticultura e Silvicultura, Faculdade de Agronomia, Universidade Federal do Rio Grande do Sul (UFRGS), Porto Alegre, RS, Brasil.
} 
decades, with particular prominence in grape juice, fresh fruit, wine, and sparkling wine exports (MELLO, 2012). This growth can be explained by the introduction of vines in areas previously used for other crops, replacement of old vineyards, and further intensification of cultivation techniques and crop management (CAMARGO et al., 2011).

In the introduction and replacement of plants in an area, the use of plant material certified for the absence of pests is the predominant practice that identifies an economically productive vineyard (KUHN et al., 2007). However, although not recommended by research, it is common for some winegrowers to produce seedlings on their property (KUHN et al., 2007), due to the easy propagation of vines (Vitis sp.) by asexual methods such as cutting (HARTMANN et al., 2011).

One of the main difficulties for grapegrowers is producing in areas where death of plants occurs by vine decline, associated with the occurrence of the ground pearl, Eurhizococcus brasiliensis, which is one of the main agents related to the death of plants (DALBÓ et al., 2007). To date, there is no effective control for this pest because the cultivation of grapes in infested areas is a common practice (BOTTON et al., 2004). Further, because nurseries, where propagation of cuttings occurs, are located near production areas in small farms, ground pearl recurs in mother plants; although, there is no information about damage by the insect in the production of future cuttings. This focus on ground pearl is even more important for seedlings of 'Paulsen 1103' (Vitis berlandieri $\times$ Vitis rupestris) because it is the main rootstock used in southern Brazil. In addition, many grape growers adopt the practice of replanting rootstocks and field grafting. It is known that infested plants tend to produce smaller branches, as observed for scion cultivars, with the possibility of small changes in starch content in the branches (ZART et al., 2014). The amount of starch present in the cutting may affect the viability and production of shoots and roots, which results in the highest quality and vigor of the seedling (ZAPATA et al., 2004). Therefore, any reduction in the health of rootstock can also affect the grafting and the initial development and survival of future seedlings, affecting the uniformity of the vineyards.

This research aimed to evaluate the starch reserve, growth, and development of rootstock seedlings of 'Paulsen 1103' from cuttings collected from stock plants cultivated in environments with and without ground pearl infestation.

\section{MATERIALS AND METHODS}

The experiment was carried out between April 2009 and January 2012 in an experimental area and laboratory of the National Center of Grape and Wine Research located in the city of Bento Gonçalves, RS, Brazil (latitude $29^{\circ} 12^{\prime} \mathrm{S}$, longitude $51^{\circ} 32^{\prime} \mathrm{W}$, and altitude $605 \mathrm{~m}$ ).

Two brick beds were used $(0.9 \mathrm{~m}$ wide $\times$ $11.4 \mathrm{~m}$ long $\times 1.0 \mathrm{~m}$ high), spaced $2.2 \mathrm{~m}$ apart. Prior to planting, the beds were homogenized to have the same soil profile, analyzed, and corrected for their chemical composition as recommended for the vine (CQFS-RS/SC, 2004).

To evaluate differences resulting from the presence of the ground pearl, two treatments were considered: 1) plants with ground pearl or infected (I) and 2) plants without ground pearl or no infected (NI). Each plant was considered a plot owing to the variability of infestation that may occur among plants in the treatment I. There were a total of 60 plots, 30 for each treatment. For the evaluation of each plot (plant) at the time of winter pruning (09/15/2011), four branches were removed (branches of the previous cycle with 12 buds) from each plant; each of these branches was subdivided into three cuttings of four buds, resulting in 12 cuttings per plant or 360 cuttings per treatment. The experimental design was completely randomized with respect to the substrate homogeneity, leveling of the beds, and sun exposure.

Prior to these treatments, the NI site underwent a preventive fumigation to eliminate a possible occurrence of ground pearl. Gastoxin ${ }^{\circledR}$ B57 aluminum phosphide (six grams of the commercial product per $\mathrm{m}^{3}$ of soil) were applied on the bed. It was then covered with a black plastic canvas for $120 \mathrm{~h}$ to ensure the effectiveness of the product. After the removal of the canvas, the bed was again tilled and prepared for planting of the seedlings in April 2009. Rooted seedlings of the cultivar 'Paulsen 1103', which came from a certified commercial seedbed free of ground pearl, were used with 30 seedlings in each bed with spacing of $0.3 \mathrm{~m} \times 0.3 \mathrm{~m}$.

In bed I, white cysts with eggs (3-5 per plant) of ground pearl were released. These eggs were collected from infested vineyards in the Serra Gaúcha during the months of November 2009/2010 and February 2010/2011, time of year in which the largest outbreaks of plague nymphs occur in the field (BOTTON et al., 2004). During the development of the seedlings in both sites (I and $\mathrm{NI}$ ), fungal diseases (with copper sulfate) and mite infestations (with Vertimec ${ }^{\circledR} 18$ EC - abamectin) 
were treated. Soil moisture was controlled using drip irrigation when needed.

In August 2009, the plants were pruned, leaving only a branch with six buds per plant, to ensure the proper growth of the mother plants. In the second year (Aug 2010), plants were pruned to ensure that only four branches with two buds each were left on each plant.. During budding (Dec 2010), excess buds were trimmed leaving four shoots per plant; in addition, they were vertically staked. Thus, the production of at least four branches (number rated per plot/plant) per mother plant was ensured, as previously described. Pruning on 09/15/2011 was conducted the same as in 2010. Branches were collected for the preparation of 360 cuttings (with four buds each) within each treatment.

All 360 cuttings of each treatment were evaluated for length, diameter, and fresh weight. For the other evaluations, the cuttings were separated into two equal groups with one group being evaluated for dry weight and starch percentage and the other group for root growth, budding, and seedling development. Therefore, the evaluations of cuttings occurred in three different stages. In the first stage, morphological aspects of all cuttings were evaluated with measurements of diameter, length, and fresh weight. In the second stage, the 360 cuttings were divided into two equal parts (180 cuttings per treatment) with one half being used for determination of dry weight. The material was dehydrated in a forced air circulation oven at $60 \pm 5^{\circ} \mathrm{C}$ for $120 \mathrm{~h}$. Further, the starch in cuttings was determined. For the length measures, the measurement between the terminal buds was taken with a graduated ruler, the diameter of the middle internode of the cutting was measured with digital calipers (Digimess brand, model 100.174 $\mathrm{BL})$, and the fresh and dry weights were measured on a digital scale $(0.01 \mathrm{~g}$ precision, brand Deltarange Mettler, model PC 4400). For starch analysis, the dried cuttings were ground in a Wiley mill, passed through a 40-mesh sieve, and reground in a mortar using liquid nitrogen until a colloidal sample formed. From these ground samples, the starch analysis was performed according to the adaptation of AMARAL et al. (2007) described by ZART et al. (2014). In the third stage, the budding, growth, and development of the seedlings were evaluated using the other half of the cuttings ( 180 cuttings per treatment). The cuttings were planted in plastic cups $\left(0.5 \mathrm{dcm}^{3}\right)$ containing a substrate of $3: 2: 1$ soil mixture: Plantmax ${ }^{\circledR}$ : vermiculite. Cups with the cuttings were placed in a greenhouse with budding evaluated 60 days after planting. For this analysis, a cutting was considered as budded if the cutting had at least one bud at the visible green tip stage (LORENZ et al., 1995). One hundred and twenty days after planting, the seedlings were evaluated for the number of shoots per cutting, number of buds per shoot, and total length of the shoots. After these evaluations, the cuttings were removed from the substrate. The number of primary roots of the cutting, length of the two largest roots, and total weight of the roots were evaluated; a rooted cutting was considered to have at least one primary root. The roots of I plants were also observed in April 2012 (36 months after planting) for the presence of ground pearl.

For all statistical analyses, the STATISTICA 6.0 software was used. The data were analyzed with ANOVA with the average of infested plants compared to the average of non-infested plants by the t-test $(\mathrm{P}=0.05)$. Mean percentages were transformed using $\mathrm{y}=\arcsin \left(\sqrt{\mathrm{x} 100^{-1}}\right)$.

\section{RESULTS AND DISCUSSION}

After 2 years of cultivation in the beds, neither symptoms of chlorosis and/or necrosis in the leaves of the infested plants nor premature abscission of the leaves was observed. In the evaluation of the roots of plants I for the number of ground pearl cysts, an average of 4.2 cysts per plant was reported, a value lower than observed by other authors under field conditions (BOTTON \& COLLETA, 2010; BROETTO et al., 2011). Despite the foliar health, the cuttings collected in beds with infestation of ground pearl (I) had, on average, smaller fresh and dry weight, shorter length, and smaller diameter when compared with the cuttings collected from the beds without infestation of ground pearl (Figure 1). This result emphasized that plants infested for two years with ground pearl suffered negative impacts on the vigor of annual shoots, reflecting in part the symptomatology observed in the field (ZART et al., 2014) for the cultivar of the hybrid vine variety Isabelle (Vitis labrusca $\times$ Vitis vinifera).

In Brazil, although regulations are not imposed on morphological characteristics in cuttings production, a recommendation exists for the use of cuttings with lengths between 28 and $30 \mathrm{~cm}$ and diameters from 0.7 to $1.2 \mathrm{~cm}$ (KUHN et al., 2007). The evaluated cuttings were below these parameters, with the cuttings taken from plants I being smaller (Figure 1). However, comparing the observed results with the standards required for the production of seedlings by cutting in France, the diameters achieved in this experiment were higher than the minimum 


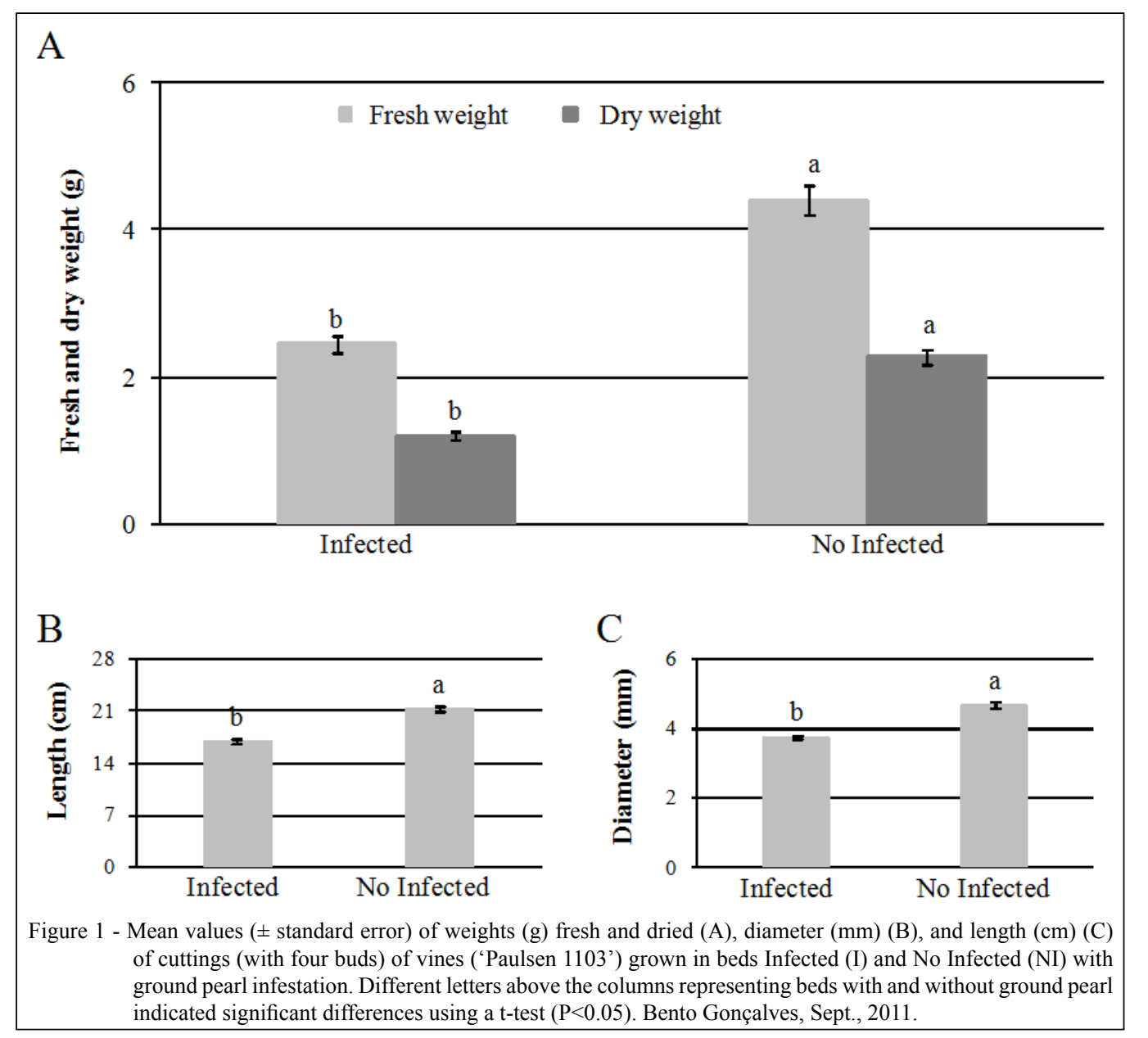

reference (3.5mm) (REGINA, 2002). However, the length did not reach the minimum required in France $(55 \mathrm{~cm})$ in either treatment (Figure 1).

Biological activities of insects, in general, are related to environmental aspects, particularly temperature, which can be considered as a pest strategy, adapting its biological cycle to the phenological synchrony of the plant (BALE et al., 2002). Therefore, if it was considered that the ground pearl has a cycle of about 1 year in southern Brazil (BOTTON et al., 2004) and that phases of higher metabolic activity and growth of the vine (increased circulation of nutrients) and of the insect are coincident in the warmer months of the year (October-April for the southern hemisphere), the lower growth observed in the branches may be a consequence of the diversion of nutrients related to the eating habits of the cochineal. Being a sucking insect, the ground pearl feeds directly from the vascular bundles of the vine, acting as a sap drain, and can divert substantial amounts of plant nutrients (ZAPATA et al., 2004).
For other species of sucking insects, the diversion of carbohydrates in alfalfa leaves by leafhoppers (PIRONE et al., 2005) and leaves and beet stems by aphids (CAPINERA, 1981) were severe enough to lead to a drop in these plants productivity. Despite the contrasts observed in the morphology of the branches between I and NI plants, possibly related to the diversion of phloem flow by the insect, the collected cuttings showed no differences in the accumulation of starch reserves (Figure 2A). This observation reflected the high capacity that the vine plants have to produce carbon compounds during vegetative growth without much interference in the accumulation of this reserve by the attack of this pest. However, considering the importance of starch accumulation in the basal buds of the vine for the initial growth and photosynthetic establishment of new shoots (MULLINS et al., 1992), the branches of the plants infested by ground pearl (I) had a lower percentage (though this difference was not significant) of total starch content (Figure

Ciência Rural, v.46, n.10, out, 2016. 


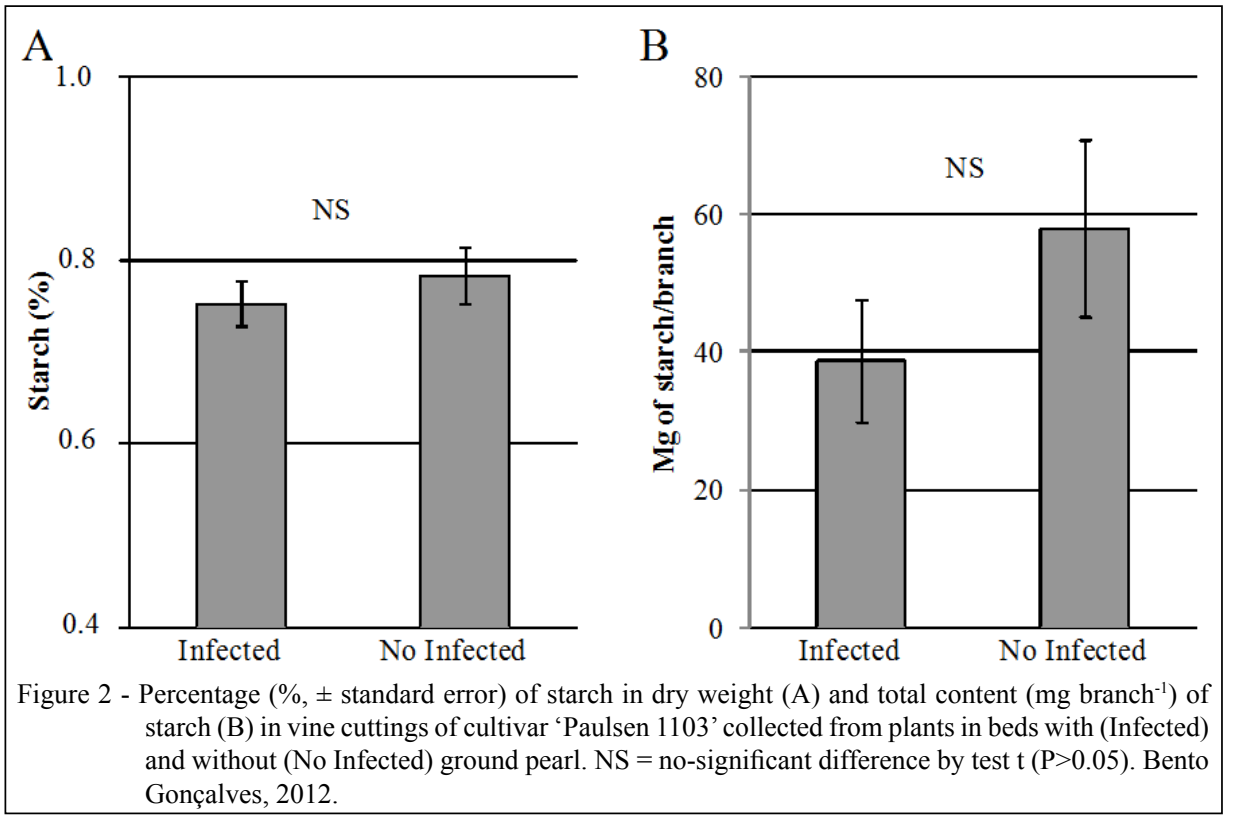

2B), which is associated with the difference in dry weight between the treatments (Figure 1A). With a higher degree of insect infestation in the roots and longer coexistence of the pest and plant, this restriction in the total starch content in I plants could limit the survival of the plants in environments with greater light restriction considering the drain of carbohydrates. Moreover, this suppression of reserves can also restrict the rate of grafting success and graft survival, since carbohydrates are important for this

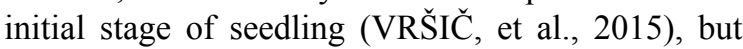
specific experiments in this area should be conducted to confirm these hypotheses.

In all cuttings of I and NI plants, at least one bud sprouted, with no significant difference between the treatments (Table 1). There was no difference in the production of roots as well; however, in observing the rooting of the cuttings, $95.6 \%$ and $96.3 \%$ of cuttings from plants from the I and NI beds, respectively, had at least one root. This response can be explained by the similarity in starch content of the plants from the I and NI beds (Figure 2). According to ZAPATA et al. (2004), starch accumulation in the cutting effectively influences the budding of the next cycle, supporting initial growth until the first leaves reach photosynthetic maturity to meet the carbon demand.

One of the factors that could determine the lower growth eported for the branches of the infested plants is the amount of starch reserves in the cuttings, a factor highlighted by LEAKEY \& COUTTS (1989); although, its importance has not been confirmed. In contrast; although, the plants I produced smaller cuttings, there is not a loss of vigor or a reduction in shoot and root development in the initial phase in the nursery without restrictions of water, light, or nutrition.

Another observed characteristic is that the plants from the beds I did not show typical

Table 1 - Mean values ( \pm standard error) of the number of shoots, number of buds, total length of shoots, number of primary roots, length $(\mathrm{cm})$ of two roots, and the fresh weight $(\mathrm{g})$ of the roots of the cuttings (Cut.) of plants grown in beds with ground pearl (I) and without ground pearl (NI). Bento Gonçalves, Dec/2011.

\begin{tabular}{|c|c|c|c|c|c|c|}
\hline Cut. & No. shoots & No. buds & Total lengtht of shoots $(\mathrm{cm})$ & No. primary roots & Length of two roots $(\mathrm{cm})$ & Fresh weight of roots(g) \\
\hline I & $1.58 \pm 0.08^{\mathrm{ns}}$ & $13.62 \pm 0.46^{\mathrm{ns}}$ & $24.10 \pm 1.24^{\mathrm{ns}}$ & $18.23 \pm 1.62^{\mathrm{ns}}$ & $27.99 \pm 0.81^{\mathrm{ns}}$ & $2.29 \pm 0.08^{\text {ns }}$ \\
\hline NI & $1.65 \pm 0.07$ & $14.35 \pm 0.48$ & $25.96 \pm 1.04$ & $20.04 \pm 1.07$ & $27.13 \pm 0.81$ & $2.14 \pm 0.10$ \\
\hline C.V. ${ }^{1}(\%)$ & 42.10 & 28.99 & 38.36 & 48.24 & 24.85 & 34.17 \\
\hline
\end{tabular}

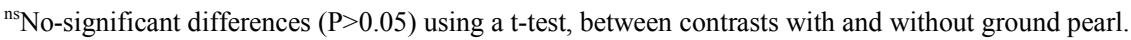

${ }^{1}$ Coefficient of variation (C.V.). 
foliar symptoms of plants attacked by ground pearl, possibly because of the number of ground pearls present in the mother plants $\left(4.2\right.$ cysts plant $\left.^{-1}\right)$ or because these symptoms are not perpetuated in shoots of detached branches. Nevertheless, leaves of the mother plants infested by ground pearl did not show characteristic symptoms of insect attack on the vine throughout the experimental period (29 months), an observation that should be considered in other studies assessing the symptoms of attack by this pest against their hosts. The absence of symptoms may be an indication that the leaf effects are manifested only after a long period of infestation of the plants, possibly more than 29 months. However, under field conditions, 'Paulsen 1103' plants, within six months of planting, were reported to have two to five cysts per plant and already manifested the symptoms of foliar chlorosis and necrosis (MARCOS BOTTON, verbal report) which are the commonly cited symptoms of ground pearl. According to BOTTON \& COLLETA (2010), plants of the rootstock '101-14' (V. riparia $\times \boldsymbol{V}$. rupestris) with 2 years of high infestation (average of 10 to 60 cysts plant $^{-1}$ ) had symptoms of infestation and did not survive. However, high infestation cannot be considered to guarantee foliar symptoms. For example, 'Paulsen 1103' plants after eight months of planting showed an average of 23 cysts of ground pearl per plant and did not show any foliar symptoms (BOTTON et al., 2010). Consistent with this finding, controversially for the association of insect presence and vine symptomatology, ZART et al. (2014) proposed the hypothesis that the foliar symptoms observed on vines attacked by ground pearl in the field may be associated with other factors, biotic or abiotic, and not specifically with the insect attack itself.

\section{CONCLUSION}

Mother plants infested by ground pearl produce smaller branches than uninfected plants. However, this effect did not compromise the initial development of the cuttings taken from these branches for either budding or shoot and root development.

\section{VERBAL REPORT}

BOTTON, M. marcos.botton@embrapa.br. Empresa Brasileira de Pesquisa Agropecuária, Embrapa Uva e Vinho, Rua Livramento, 515, CEP: 95700-000, Bento Gonçalves, Rio Grande do Sul, Brasil. Reunião técnica sobre pérola-da-terra. Comunicação pessoal: em 13 abr. 2011.

\section{REFERENCES}

AMARAL, L.I.V. do et al. A new rapid and sensitive enzymatic method for extraction and quantification of starch in plant material Hoehnea, São Paulo, v.34, p.425-431, 2007. Available from: $<$ http://www.scielo.br/scielo.php?script=sci_arttext\&pid=S223689062007000400001\&lng=pt\&nrm=iso>. Accessed: Dec. 25, 2009. doi: 10.1590/S2236-89062007000400001.

BALE, J.S. et al. Herbivory in global climate change research: direct effects of rising temperature on insect herbivores. Global Change Biology, Malden, Massachusetts, n.8, p.1-16, 2002. Available from: <http://onlinelibrary.wiley.com/doi/10.1046/ j.1365-2486.2002.00451.x/abstract>. Accessed: Dec. 25, 2009. doi: 10.1046/j.1365-2486.2002.00451.x.

BOtTON, M. et al. Pérola-da-terra. In: SALVADORI, J.R. et al. Pragas de solo no Brasil. Passo Fundo: Embrapa Trigo; Dourados: Embrapa Agropecuária Oeste; Cruz Alta: Fundacep, 2004. p.457-476.

BOTTON, M.; COLLETA, V.D. Evaluation of the resistence of Vitis rotundifolia cultivars to brazilian ground pearl (Hemiptera: Margarodidae) in southern Brazil. Acta Scientiarun Agronomy, Maringá, v.32, n.2, p.213-216, 2010. Available from: <http://www. scielo.br/pdf/asagr/v32n2/a04v32n2.pdf $>$. Accessed: May 15, 2011. doi: 10.4025/actasciagron.v32i2.3151.

BOTTON, M. et al. Use of soil insecticides to control the Brazilian ground pearl (Hemiptera: Margarodidae) in vineyards. Revista Colombiana de Entomología, Bogotá, v.36, n.1, p.20-24, 2010. Available from: <http://www.scielo.org.co/pdf/rcen/v36n1/ v36n1a05.pdf $>$. Accessed: May 15, 2011.

BROETTO, D. et al. Development and occurrence off ground pearl in vitis grafted on 'VR 043-43' and 'Paulsen 1103'. Revista Brasileira de Fruticultura, Jaboticabal, v.33, n.1, p.404-410, 2011. Available from: <http://www. scielo.br/scielo.php?script $=$ sci_arttext $\&$ pid $=S 0100-$ 29452011000500052\&lng=en\&nrm=iso $>$. Accessed: Jan. 01, 2012: doi: 10.1590/S0100-29452011000500052.

CAMARGO, U.A. et al. Advances in grape culture in Brazil. Revista Brasileira de Fruticultura, Jaboticabal, v.33, n.spe. p.144-149, 2011. Available from: <http:// www.scielo.br/scielo.php? script $=$ sci_arttext\&pid $=$ S010029452011000500017\&lng=en\&nrm=iso $>$. Accessed: Jan. 01, 2011. doi: 10.1590/S0100-29452011000500017.

CAPINERA J. Some effects of infestation by bean aphid, Aphis fabae Scopoli, on carbohydrate and protein levels in sugarbeet plants, and procedures for estimating economic injury levels. Zeitschriftfür Angewandte Entomologie, Berlin, v.92, p.374384, 1981. Available from: <http://onlinelibrary.wiley.com/ doi/10.1111/j.1439-0418.1981.tb01686.x/abstract>. Accessed: Dec. 25, 2009. doi: 10.1111/j.1439-0418.1981.tb01686.x.

CQFS-RS/SC (COMISSÃO DE QUÍMICA E FERTILIDADE DO SOLO - RS/SC). Manual de adubação e calagem para os Estados do Rio Grande do Sul e de Santa Catarina. 10.ed. Porto Alegre: SBCS - Núcleo Regional Sul/UFRGS, 2004. 400p.

DALBÓ, M.A. et al. Management alternatives to control grape decline in South of Brazil. Agropecuária Catarinense, Florianópolis, v.20, n.1, p.58-61, 2007. Available from: $<$ https:// www.researchgate.net/publication/263088759_Alternativas_ 
de_manejo_para_o_controle_do_declinio_da_videira $>$. Accessed: Dec. 25, 2009.

HARTMANN, H.T. et al. Plant propagation: principles and practices. 8.ed. New Jersey: Prentice Hall, 2011. 912p.

KUHN, G.B. et al. Produção de mudas de videira (Vitis spp.) por enxertia de mesa. Bento Gonçalves: EMBRAPA/CNPUV, 2007. 12p. (Circular técnica, 74). Available from: <http://www. cnpuv.embrapa.br/download.php?file=publica/circular/cir074. pdf>. Accessed: May 15, 2012.

LEAKEY, R.R.B.; COUTTS, M.P. The dynamics of rooting in Triplochiton scleroxylon K. Schum. cuttings-their relationship to leaf area, node position, dry weight accumulation, leaf water potential and carbohydrate composition. Tree Physiology, London, v.5, p.135-146, 1989. Available from: $<$ http://treephys.oxfordjournals.org/content/5/1/135.full.pdf $>$. Accessed: Dec. 25, 2009.

LORENZ, D.H. et al. Phenological growth stages of grapevine (Vitis vinifera L.) - Codes and descriptions according to the extended $\mathrm{BBCH}$ scale. Australian Journal of Grape and Wine Research, Adelaide, v.1, p.100-103, 1995. Available from: <http://onlinelibrary.wiley.com/ doi/10.1111/j.1755-0238.1995.tb00085.x/abstract>. Accessed: Dec. 25, 2009. doi: 10.1111/j.1755-0238.1995.tb00085.x.

MELlO, L.M.R. de. Atuação do Brasil no Mercado Vitivinícula Mundial - Panorama 2011. Bento Gonçalves: EMBRAPA/CNPUV, 2012. (Comunicado Técnico 116). Available from: <http://www.infoteca.cnptia.embrapa.br/ handle/doc/926520>. Accessed: May 15, 2012.

MULLINS, M.G. et al. Biology of grapevine. New York: Cambridge University, 1992. 239p.
PIRONE, C.L. et al. Patterns of starch accumulation in alfalfa subsequent to potato leafhopper (Homoptera: Cicadellidae) injury. Environmental Entomology, Lanham, v.34, p.199-204, 2005. Available from: <http://ee.oxfordjournals.org/content/ ee/34/1/199.full.pdf $>$. Accessed: Dec. 25, 2009. doi: 0046225X/05/0199-0204\$04.00/0

REGINA, M. de A. Production and certification of grapevine plants in France. 2. The technique of plants production by table grafting. Revista Brasileira de Fruticultura, Jaboticabal, v.24, n.2, p.590-596, 2002. Available from: $<$ http:// www.scielo.br/scielo.php? script $=$ sci_arttext\&pid $=\mathrm{S} 0100$ 29452002000200065\&lng=en\&nrm=iso $>$. Accessed: Dec. 25, 2009. doi: 10.1590/S0100-29452002000200065.

VRŠIČ, S, et al. Factors influencing grafting success and compatibility of grape rootstocks. Scientia Horticulturae, Amsterdam, n.181, p.168-173, 2015. Available from: $<$ https://www. researchgate.net/profile/Stanko_Vrsic2/publication/268773003 Factors_Influencing_Grafting_Success_and_Compatibility_ of_Grape_Rootstocks/links/548069980cf5250f1edc19732.pdf $>$. Accessed: May 15, 2015. doi: 10.1016/j.scienta.2014.10.058.

ZAPATA, C. et al. Partitioning and mobilization of starch and $\mathrm{N}$ reserves in grapevine (Vitis vinifera L.). Journal of Plant Physiology, Leipzig, v.161, p.1031-1040, 2004. Available from: $<$ https://www. researchgate.net/profile/Christian_Magne/publication/8217004_ Partitioning and mobilization of starch and N reserves in grapevine_(Vitis_vinifera_L.)/links/5498539f0cf2c5a7e342bb13. pdf $>$. Accessed: Dec. 25, 2009. doi: 10.1016/j.jplph.2003.11.009.

ZART, M. et al. Caracterização morfo-fisiológica de plantas de videira atacadas por pérola-da-terra. Semina, Londrina, v.35, n.3, p.1187-1200, 2014. Available from: <http://ainfo.cnptia.embrapa. br/digital/bitstream/item/112374/1/13730-78024-1-PB.pdf $>$. Accessed: Jul. 01, 2014. doi: 10.5433/1679-0359.2014v35n3p1187. 